\title{
Combined effects of dietary HUFA level and temperature on sea bass (Dicentrarchus labrax) larvae development
}

\author{
M. Vagner ${ }^{a,{ }^{*}}$, J.H. Robin ${ }^{a}$, J.L. Zambonino Infante ${ }^{a}$ and J. Person-Le Ruyet ${ }^{a}$ \\ aUMR 1067 INRA-IFREMER-Bordeaux 1, IFREMER Centre de Brest, BP 70, 29280 Plouzané, France \\ *: Corresponding author : mvagner@ifremer.fr
}

\begin{abstract}
:
The purpose of this study was to investigate the combined effect of the incorporation of vegetable products in diet and temperature on enzymatic pathways for high unsaturated fatty acids (HUFA) desaturation in sea bass larvae. Four replicated groups were fed a low (LH; $0.8 \%$ EPA + DHA) or a high $(\mathrm{HH} ; 2.2 \%$ EPA + DHA) n-3 HUFA microparticulated diet from mouth opening, six days posthatching and were reared at 16 or $22^{\circ} \mathrm{C}$. The four experimental conditions (LH16, HH16, LH22 and $\mathrm{HH} 22$ ) were tested for 45 days. At the end of the experiment, body weight, total length and biomass were affected by temperature $(P<0.001)$, while biomass as well as fresh body weight was also influenced by diet $(P<0.05$ and $P<0.001$ respectively). This always lead to the same ranking of experimental conditions: $\mathrm{HH} 22>\mathrm{LH} 22>\mathrm{HH} 16>\mathrm{LH} 16$. The larval skeletal development was more advanced in $22^{\circ} \mathrm{C}$-groups than in $16^{\circ} \mathrm{C}$-ones $(P<0.001)$, while it was not affected by diet. Amylase and trypsin pancreatic secretions did not vary between $d-25$ and $d-45$, indicating that pancreatic maturation was achieved at $d-25$. Low temperature combined with low dietary HUFA delayed intestinal maturation $(P<0.001)$, while low temperature combined with high HUFA diet allowed larvae compensating for the initial intestinal maturation retardation. Lipase gene expression was downregulated in $\mathrm{HH} 16$ group at $\mathrm{d}-25(P<0.05)$ and in the two $16{ }^{\circ} \mathrm{C}$-groups at $\mathrm{d}-45(P<0.001)$, while lipase enzymatic activity was similar in all groups. This suggested the presence of a posttranscriptional regulation of this gene. PPAR $\alpha$ and PPAR $\beta$ were not affected neither by temperature, nor by diet, suggesting that lipid metabolism was not significantly affected by a lowering in dietary n-3 HUFA when isolipidic diets were used. A higher DHA content was found in larvae than in their diets ( $\times 2$ for $\mathrm{LH} ; \times 1.5$ for $\mathrm{HH}$ ) but the DHA content in PL of d-45 LH larvae was lower than the initial one, which revealed a HUFA deficiency in this group. Delta 6-desaturase $(\triangle 6 \mathrm{D})$ gene expression was significantly up-regulated by HUFA deprived diet $(P<0.05)$ whatever the temperature was. This was supported by the increase in 18:3n-6 in LH larvae $(P<0.001)$, which indicated a desaturation from $18: 2 n-6$ by the $\triangle 6 \mathrm{D}$. This study clearly showed that larvae were able to adapt to an $n-3$ deprived diet by a stimulation of enzymatic pathways for HUFA desaturation, and that this adaptation was not affected by temperature.
\end{abstract}

Keywords: Aquaculture; Delta-6 desaturase; Dicentrarchus labrax; HUFA; Desaturation 


\section{Introduction}

In marine fish, larval stage represents a transitional ontogenetic period of simultaneous growth and development, which causes substantial changes in structure, physiology and morphology, all of which modify the physiological and behavioural capabilities and subsequently the ability of the fish to deal with challenges to its survival (Fuiman, 1997). Larval development strongly depends on environmental parameters, such as temperatures, and on diet (Koumoundouros et al., 1999; Sargent et al., 1999). In particular, the importance of dietary n-3 high unsaturated fatty acids (HUFA, eicosapentaenoic EPA 20:5n-3, docosahexaenoic DHA 22:6n-3 and arachidonic ArA 20:4n-6 acids) influence on larvae has been demonstrated by several studies (Kanazawa, 1993; Koven et al., 2001) as they function as critical structural and physiological components of the cell membranes of most tissues and are essential for growth, development and survival (for review, see Sargent et al., 1999). A dietary deficiency in DHA in larvae of farmed marine teleosts has been correlated with poor growth, high mortality and susceptibility to stress and disease (Cahu et al., 2003; Robin and Peron, 2004).

In contrast to freshwater fish, marine fish require the presence of preformed HUFA in their diet as they have a low capacity to bioconvert 18 carbon atom fatty acids (linoleic 18:2n-6 and alpha-linolenic 18:3n-3) into HUFA with 20 or 22 carbon atoms (arachidonic 20:4n-6, EPA and DHA; Mourente and Tocher, 1994). The first step of this bioconversion pathway requires the presence of the delta 6-desaturase gene $(\Delta 6 \mathrm{D})$. This gene has been cloned in several freshwater species such as zebrafish (Danio rerio AF309556), common carp (Cyprinus carpio AF309557), rainbow trout (Onchorhynchus mykiss; Seiliez et al., 2001). $\Delta 6 \mathrm{D}$ gene has also been cloned in two marine fish species: gilthead seabream and turbot (Seiliez et al., 2003; Zheng et al., 2004). In gilthead seabream, an enhanced expression of the gene was obtained by feeding juveniles a HUFA-free diet. Cho et al. (1999) and Seiliez et al. (2001) previously showed that dietary HUFA inhibits the $\triangle 6 D$ gene expression in mammals and in rainbow trout. The deficiency in $\triangle 6 \mathrm{D}$ activity usually observed in marine fish can be related to the abundance of HUFA n-3 in marine food chain, which has induced an adaptation (Sargent et al., 1995) or a repression of the $\triangle 6 \mathrm{D}$ activity (Olsen et al., 1990).

As long as fish oil and meals represent primarily ingredients of aquafeeds, larvae n-3 HUFA requirements are easily covered. However, the high increase in farmed fish production in addition to the stagnation or rarefaction of natural stocks lead to look at substitutes for fish products commonly used in aquaculture (Lodemel et al., 2001; Ringo et al., 2002). Incorporation of vegetable compounds in fish feeds constitutes at the present time the only solution in Europe, although it do not bring $n-3$ HUFA to cover marine fish requirement but PUFAs with 18 carbons (C18), which may disturb fish physiology (Parpoura and Alexis, 2001). So it should be interesting to obtain fish able to adapt their metabolism developing enzymatic pathways in order to bioconvert C18 fatty acids supplied by vegetable products into HUFA. However, in larval stages this capacity could be affected by environmental factors, specially by temperature, which is one of the greatest factors acting on fish ontogeny (Koumoundouros et al., 1999). Interaction between temperature and dietary n-3 HUFA has been investigated in European sea bass juveniles (Person-Le Ruyet et al., 2004) and showed that a 3-month deficiency in dietary n-3 HUFA did not drastically impair fish capacity to adapt to a high temperature $\left(29^{\circ} \mathrm{C}\right)$. 
The aim of this study was to examine the effect of specific dietary n-3 HUFA combined with water temperature on the development of some metabolic functions, particularly on the enzymatic pathways for HUFA desaturation during sea bass (Dicentrarchus labrax) larval development. The expression of $\Delta 6 \mathrm{D}$ in response to these experimental conditions was specially studied.

\section{Materials and methods}

\subsection{Rearing conditions and experimental design}

Three days post-hatching sea bass larvae were obtained from the commercial fish farm Aquanord (Gravelines, France) and experiments were conducted at the IFREMER-Brest. Larvae were dispatched in 20 conical fiberglass

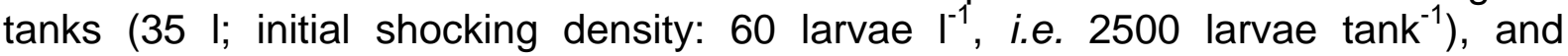
temperature was progressively increased from $14^{\circ} \mathrm{C}$ to $16^{\circ} \mathrm{C}$ within 2 days. After an acclimation period of 2 days, temperature was progressively increased to $22^{\circ} \mathrm{C}$ in 8 tanks while other tanks remained at $16^{\circ} \mathrm{C}$. All groups were fed microparticulated diets from mouth opening at day $6(\mathrm{~d}-6)$ to $\mathrm{d}-45$. Larvae weighted $0.36 \pm 0.01 \mathrm{mg}$ at $\mathrm{d}-6$. Two isolipidic diets (Table 1) differenced by a low (LH) or high (HH) HUFA content were tested: 0.8 and 2.2\% EPA+DHA on dry matter basis, respectively. The four experimental conditions were $\mathrm{LH} 16, \mathrm{HH} 16, \mathrm{LH} 22$ and $\mathrm{HH} 22$, with 6 tanks per conditions at $16^{\circ} \mathrm{C}$ and 4 at $22^{\circ} \mathrm{C}$. Diets were automatically distributed in excess $18 \mathrm{~h} / 24 \mathrm{~h}$ and the daily ration was progressively increased from $1 \mathrm{~g}$ per day per tank at $\mathrm{d}-6$ to $10 \mathrm{~g}$ at $\mathrm{d}-45$.

Tanks were supplied with running sea water (34.5\%o) filtered through a sand filter, then passed successively through a tungsten heater and degassing column packed with plastic rings. The water renewing was progressively increased from $50 \%$ $\mathrm{h}^{-1}$ at $\mathrm{d}-6$ to $200 \% \mathrm{~h}^{-1}$ at $\mathrm{d}-45$, which allowed stabilizing oxygen saturation around $95 \pm 2 \%$ and preventing of ammonia accumulation. Larvae were exposed to full darkness until $d-7$ and then light cycle was 24L:OD until d-45: light intensity was progressively increased from 1 to 500 lux, during this period.

\subsection{Sampling procedures}

Fish were fasted for $12 \mathrm{~h}$ and the water volume was lowered prior to random sampling at d-25 and at d-45 using an appropriate net. These two sampling periods were selected as they correspond to the beginning of the development of digestive enzymes specific to the brush border membrane (BBM, d-25) and to the end of the larval period, when all enzymatic and molecular functions are established (d-45).

Growth performances were monitored by sampling 30 larvae in four tanks per condition $(n=120)$. Fish were then fixed in $4 \%$ seawater formalin. After a minimum preservation period of three weeks, larvae were individually weighed $\left( \pm 10^{-2} \mathrm{mg}\right)$ and then pooled and dried for $24 \mathrm{~h}$ at $105^{\circ} \mathrm{C}$ to estimate the dry weight of each group $(\mathrm{n}=$ 4). Final biomass expressed in $\mathrm{mg} \mathrm{l}^{-1}$ was the larvae fresh mean weight per final number at $\mathrm{d}-45$. The apparent survival rate was estimated for each experimental group using the ratio initial/final number of larvae in each tank ( $n=6$ for $16^{\circ} \mathrm{C}$ conditions and $\mathrm{n}=4$ for $22^{\circ} \mathrm{C}$ groups).

To monitor growth in length and determine the different developmental stages, 10 additional larvae were taken from each tank ( $n=40$ per experimental condition) and 
fixed in $4 \%$ seawater formalin. For less than $13 \mathrm{~mm}$ total length larvae a TNPC ${ }^{\circledR} 3.2$ software connected to a binocular microscope was used, while a calliper square for bigger larvae (Codiam-Scientific $($ ) $)$. Developmental stages were determined after using the coloration with alcian blue and alzarin red described by Taylor and Van Dyke (1985). Morphological criterions described by Sfakianakis et al. (2004) for common pandora Pagellus erythrinus and adapted to sea bass were used.

Enzymatic analyses were performed on 50 pooled larvae sampled in four tanks per condition $(n=4)$ and stored at $-20^{\circ} \mathrm{C}$ before dissection. Dissections under a binocular microscope were conducted on a glass maintained at $0^{\circ} \mathrm{C}$. Pancreatic and intestinal segments (PS and IS) were extracted in each larvae as described by Cahu and Zambonino Infante (1994) in order to limit the assay of enzymes to specific segments, and were then stored at $-20^{\circ} \mathrm{C}$ pending analysis.

Measurement of relative expression of genes involved in digestive functions and lipid metabolism was performed on $150 \mathrm{mg}$ of larvae in three tanks per condition $(\mathrm{n}=3)$ conserved in trizol at $-80^{\circ} \mathrm{C}$ pending analysis: delta- 6 desaturase $(\Delta 6 \mathrm{D})$, lipase, phospholipase $A 2\left(P L A_{2}\right)$, peroxisome proliferator activated receptors alpha (PPAR a) and beta (PPAR $\beta$ ).

For body composition and lipid analysis, 50 pooled larvae were sampled and weighted in four tanks per condition $(n=4)$ and conserved at $-80^{\circ} \mathrm{C}$ pending analysis.

\subsection{Analytical methods}

\subsubsection{Digestive enzyme assays}

Pooled pancreatic segments (PS) of the same tank were homogenised in five volumes of ice-cold distilled water and pooled intestinal segments (IS) in 30 volumes Tris-Mannitol buffer. One $\mathrm{ml}$ was taken in order to assay secreted pancreatic enzymes (trypsin and amylase) and a cytosolic peptidase of the enterocyte (leucinealanine peptidase, leu-ala). The remaining homogenate was processed in order to assess enzymes of the brush border membrane BBM (leucine aminopeptidase LAP and alkaline phosphatase AP) after a purification according to a method developed for intestinal scraping (Crane et al., 1979).

Pancreatic enzymes were assayed according to Holm et al. (1988) and Metais and Bieth (1968), respectively in PS and IS. Lipase was assayed according to the non specific method of lijima et al. (1998). BBM enzymes were assayed according to Maroux et al. (1973) and Bessey et al. (1946) respectively. Assay of leu-ala, was performed using the method of Nicholson and Kim (1975).

Enzyme activities were expressed as specific activities (U mg protein ${ }^{-1}$ ), i.e., the total activity of each enzyme per larvae in the segment. Protein was determined by the Bradford procedure (1976). Secretion (\%) of pancreatic enzymes (1) and the digestive tract maturation (2) were calculated as Zambonino and Cahu (2001):

$$
\begin{aligned}
& S=I /(I+P) \\
& I=\text { enzyme activity assayed in the intestinal segment }\left(U . \text { segment }{ }^{-1}\right) \\
& \quad P=\text { enzyme activity assayed in pancreatic plus intestinal segments }\left(U \text { segment }^{-1}\right) .
\end{aligned}
$$

Enzyme activity in BBM (U segment $\left.{ }^{-1}\right) /$ leu-ala activity in IS (U segment $\left.{ }^{-1}\right)$

\subsubsection{Gene expression}

cDNA were obtained in duplicate from total RNA by using Quantitect Reverse Transcription kit with integrated removal of genomic DNA contamination (QIAGEN® 
$\mathrm{GmbH}$, Hilden, Germany). Real-time PCR was performed using the iCycler iQTM (Bio-Rad $\circledast$ Laboratories Inc.). Quantitative PCR analyses for each gene were performed in triplicate for each cDNA duplicate (6 assays for each studied gene per experimental group), in a total volume of $15 \mu$ l containing $5 \mu l$ cDNA (dilution: 10-2),

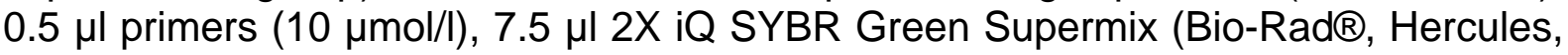
$\mathrm{CA})$. The specificity of forward and reverse primers of each gene was checked by sequencing the amplicon (Table 2; Eurogentec, Labège, France). Thermal cycling was initiated with incubation at $95^{\circ} \mathrm{C}$ for $13.5 \mathrm{~min}$ for activation of the hot-start enzyme, iTaqTM DNA Polymerase. After this initial step, 45 cycles of PCR were performed. Each PCR cycle consisted in heating at $95^{\circ} \mathrm{C}$ for $30 \mathrm{sec}$ for denaturing, at $60^{\circ} \mathrm{C}$ for $1 \mathrm{~min}$ for annealing and extension. Cycle threshold values (CT) corresponded to the number of cycles at which the fluorescence emission monitored in real time exceeded the threshold limit. Standard curves were established for each gene by plotting the CT values against the log10 of 5 different dilutions (in triplicate) of cDNA sample solutions. Real-time PCR efficiency $E$ was determined for each gene from the given slopes in Bio-Rad ${ }^{\circledR}$ software, according to the equation 3 :

$E=10[-1 /$ slope $]$

The relative expression ratio of each gene was calculated using REST ${ }$ software (http://www.wzw.tum.de/gene-quantification/) and is based on the PCR efficiency (E) and the CT of a sample versus the control (standard group), and expressed in comparison to the reference gene (elongation factor EF1), according to Pfaffl's mathematical model (Pfaffl, 2001):

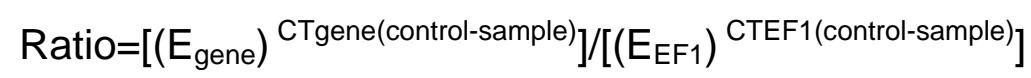

In this study, $\mathrm{HH} 22$ was used as the standard group because it is close to the rearing condition in fish farming. Normalization relative to EF1 provided a widely applicable value for comparative studies of gene expression at the mRNA level seeing that its expression is constant during activation and proliferation of cells (Gause and Adamovicz, 1994).

\subsubsection{Fatty acid composition}

Whole frozen fish were rapidly homogenised at $0^{\circ} \mathrm{C}$ using a Polytron ${ }^{\circledR}$ (PT 2100 Bioblock $\AA)$. A representative portion $(\sim 1 \mathrm{~g})$ was taken for analysis and $\sim 3 \mathrm{~g}$ were taken for dry weight measurement $\left(105^{\circ} \mathrm{C} ; 24 \mathrm{~h}\right)$. For lipid analyses of larvae, an internal standard (tricosanoic acid 23:0) was added, on a weighted known quantity of larvae, then extraction of total lipid (TL) was done according to Folch et al. (1957) with chloroform replaced by dichloromethane. Lipids sub sample (around $3 \mathrm{mg}$ in 50 $\mu \mathrm{l})$ were deposited at the top of a sepack light silica micro-column, neutral lipids (NL) and free fatty acids (FA) were eluted with $6 \mathrm{ml} \mathrm{CHCl}-\mathrm{MeOH}(98: 2 \mathrm{v} / \mathrm{v}$ ), then phospholipids (PL) were eluted with $8 \mathrm{ml} \mathrm{MeOH} \mathrm{(Marty} \mathrm{et} \mathrm{al.,} \mathrm{1992).} \mathrm{These} \mathrm{fractions}$ as well as a TL sub sample were transmethylated in $2 \mathrm{ml} 1 \% \mathrm{H}_{2} \mathrm{SO}_{4}$ in $\mathrm{MeOH}$ and 1 $\mathrm{ml}$ of toluene was added in NL. Fractions were stored overnight at $50^{\circ} \mathrm{C}$. Fatty acid methyl esters (FAME) neutralized with $2 \% \mathrm{KHCO}_{3}$ were extracted twice with $5 \mathrm{ml}$ hexane-diethyl ether (1:1). All FAME were separated by gas-liquid chromatography (GLC; Auto-system Perkin-Elmer ${ }^{\circledR}$ with a flame ionisation detector, BPX 70 capillary column: $25 \mathrm{~m} \times 0.22 \mathrm{~mm}$ i.d. $\times 0.25 \mu \mathrm{m}$ film thickness; split-splitless injector, with helium as carrier gas). The injector and detector temperatures were, 220 and $260^{\circ} \mathrm{C}$ 
respectively. Data acquisition and handling were carried out by connecting the GLC to a PE Nelson computer. Internal standard let to quantify FAME by internal standardisation in TL and NL on larvae fresh matter basis. The results of individual FA composition were expressed as percent of total identified FAME.

Chemical analyses of feed were performed in duplicates for each sample according to AOAC (Association of Official Analytical Chemists, 1984) methods: ash $\left(7 \mathrm{~h}\right.$ at $550^{\circ} \mathrm{C}$ ), crude fat (Folch et al., 1957), crude protein (Dumas method with an Elementary NA $\left.2000^{\circledR}, \mathrm{N} \times 6.25\right)$.

\subsection{Statistical analysis}

The data are presented as mean \pm S.E. of the replicate groups. Effects of temperature and diet on growth performances, enzymatic activities and fatty acid composition were tested using two-way ANOVA (Statistica $\AA$ ). When significant interactions occurred, differences between means were compared by Newman-Keuls test. Differences were considered significant at $P<0.05$. Data on survival, body weight and fatty acid percentages were transformed by arcsine square root before applying ANOVA. Statistical differences in gene expression between control and samples were evaluated in group means by randomisation tests (Pfaffl et al., 2002) using REST ${ }^{\circledR}$ software. Two thousand random allocations were performed and significant differences were considered at $\mathrm{P}<0.05$.

\section{Results}

\subsection{Growth performances at $d-45$}

Growth performances at d-45 are reported in Table 3. Temperature and diet had a significant effect on fresh body weight, which was almost 6 -fold higher at $22^{\circ} \mathrm{C}$ than at $16^{\circ} \mathrm{C}$ and 5 -fold higher in $\mathrm{HH}$ groups than in $\mathrm{LH}$ ones. Final biomass was significantly affected by both temperature and diet, it was 3-fold higher in $\mathrm{HH} 22$ than in LH16 groups. Total length was more significantly affected by temperature than by diet. Apparent larvae survival rate was significantly affected by temperature and was more than twofold higher in $16^{\circ} \mathrm{C}$ groups than in $22^{\circ} \mathrm{C}$ ones.

\subsection{Skeletal developmental stage}

The skeletal development was significantly less advanced at $16^{\circ} \mathrm{C}$ than at $22^{\circ} \mathrm{C}$ at $\mathrm{d}-25$ and $\mathrm{d}-45$ (Fig.1). At d-25, about $95 \%$ of larvae at $16^{\circ} \mathrm{C}$ belong to $\mathrm{B}$ stage, while at $22^{\circ} \mathrm{C}$ they are quite evenly distributed in stages $\mathrm{C}$ and $\mathrm{D}$. At $\mathrm{d}-45$, the dominant class was stage $\mathrm{E}$ at $16^{\circ} \mathrm{C}$ and stage $\mathrm{F}$ at $22^{\circ} \mathrm{C}$. Fig. 2 showed the mean length per each developmental stage and extreme values. This relationship was not regular and mean total length of one developmental stage was significantly different from the mean total length of the successive stage ( $T$-test: $P<0.05$ between $C$ and $D$; $P<0.01$ between $B$ and $C$ and $P<0.001$ between $A$ and $B, D$ and $E, E$ and $F$ and $F$ and $G)$. 


\subsection{Enzymatic activities}

Amylase pancreatic secretion was steady between $\mathrm{d}-25$ and $\mathrm{d}-45$ (NS) and varied from $59.0 \pm 7.3 \%$ for LH16 group to $70.0 \pm 3.4 \%$ for $\mathrm{HH} 16$ one at d-25 and from $52.8 \pm 11.1 \%$ for $\mathrm{LH} 22$ group to $65.9 \pm 2.4 \%$ for LH16 one at d-45 (Fig.3A). The same result was observed concerning trypsin secretion in pancreas.

At d-25, AP/leu-ala maturation ratio, indicative of intestinal maturation, was significantly influenced by temperature (Fig.3B; $P<0.001)$, diet $(P<0.05)$, and interactions occurred between these two parameters $(P<0.001)$. Maturation ratio measured in each group were significantly different each from each other. Larvae conditioned at $16^{\circ} \mathrm{C}$ showed the lowest maturation ratio $(1.3 \pm 0.1$ for LH-groups and $2.1 \pm 0.2$ for $\mathrm{HH}$-ones), while the highest was observed in 22 groups (7.0 \pm 0.5 and $5 \pm 0.1$ for $\mathrm{LH}$ and $\mathrm{HH}$ groups respectively). At d-45, no significant differences were observed but HH16 groups reached the same maturation level as LH22 (around 9), conversely to groups LH16 with the lowest maturation level (3.1 \pm 0.3$)$. L-aminopeptidase (LAP)/leu-ala ratio is also an indicator of intestinal maturation and the same results as for AP/leu-ala were observed for this enzyme.

\subsection{Gene expression}

At $\mathrm{d}-25$, the lipase gene expression ratio relative to $\mathrm{HH} 22$ group (Fig.4A) was significantly 4.6 times down-regulated in $\mathrm{HH} 16$ groups $(\mathrm{P}<0.05)$. At $\mathrm{d}-45$, it was also 2.5 and 2.8 times significantly down-regulated in $\mathrm{HH} 16$ and in $\mathrm{LH} 16$ groups respectively $(P<0.001)$. Non specific lipase enzymatic activity was not significantly influenced by temperature and diet (Fig.4B) neither at d-25 nor at d-45.

At d-25, the $\triangle 6 D$ gene relative expression significantly increased in groups fed LH diet with a factor of 3.2 in both $\mathrm{LH} 16$ and $\mathrm{LH} 22$ groups (Fig.5; $\mathrm{P}<0.05$ ). At $\mathrm{d}-45$, $\triangle 6 \mathrm{D}$ expression was 3.3 and 5.8 times significantly up-regulated in LH16 $(P<0.05)$ and LH22 $(P<0.001)$ groups respectively. $\mathrm{PLA}_{2}$ was 2.5 times significantly downregulated $(P<0.001)$ in $\mathrm{HH} 16$ group. PPAR $\alpha$ and PPAR $\beta$ gene expressions were not significantly affected by temperature nor diet at $d-25$ or at $d-45(P>0.05)$.

\subsection{Fatty acid composition}

Total FAME content in d-45 larvae in fresh weight basis was not significantly affected by treatments (Table 4). However, neutral lipid (NL) content was higher in $22^{\circ} \mathrm{C}$ groups than in $16^{\circ} \mathrm{C}$ ones $(P<0.05)$. FAME in NL represented from $50 \%$ (LH16) to $64 \%$ (LH22) of total FAME. NL composition in d-45 larvae closely reflected that of diets (Table 1 and 4). HUFA (ArA, EPA and mainly DHA) were selectively incorporated in polar lipids (PL) and a quantitative estimation (Fig.6) let to calculate that DHA in PL represented 85\% in LH16; 80\% in $\mathrm{LH} 22,75 \%$ in $\mathrm{HH} 16,72 \%$ in $\mathrm{HH} 22$ of DHA in total lipids (TL). In total FAME content (not detailed here) a higher DHA content was measured in larvae than in their diet (7.6 and $15.2 \%$ of total FAME in $\mathrm{LH}$ and $\mathrm{HH}$ d-45 larvae versus 3.7 and $9.7 \%$ FAME in $\mathrm{LH}$ and $\mathrm{HH}$ diets respectively). Moreover, HH groups contained a higher HUFA content than LH ones in PL as well as in NL. All fatty acid levels in larvae were significantly affected by diet $(P<0.001)$. Several significant influences of temperature were also observed on 18:3n-6, 18:3n-3 and 20:5n-3 contents in NL, and on 18:2n-6, 20:4n-6, 18:3n-3 and 20:5n-3 contents in PL, inducing less dramatic differences than diets. Significant interactions also occurred on $20: 5 n-3$ in $\mathrm{PL}$ (lower in $\mathrm{HH}$ larvae at $22^{\circ} \mathrm{C}$ than at 
$16^{\circ} \mathrm{C}$ ), and on 18:3n-6 in NL content (higher in LH larvae and lower in $\mathrm{HH}$ larvae at $22^{\circ} \mathrm{C}$ than at $16^{\circ} \mathrm{C}$ ). The $18: 3 \mathrm{n}-6$ content was higher in $\mathrm{LH}$ larvae than in $\mathrm{HH}$ ones $(\mathrm{P}<0.001$; in NL as well in $\mathrm{PL})$ and than in their diet (0.1\% FAME).

\section{Discussion}

The main objective of this study was to assess whether it was possible to enhance $\triangle 6 \mathrm{D}$ expression in sea bass larvae through different rearing strategies based on a lowering in dietary HUFA supply and rearing temperature.

As expected, high temperatures lead to major increase in mass gain as well as growth in length and, to a less extend, to final biomass. Positive effect of temperature on larval growth performances has already been described in several studies (Fuiman et al., 1998; Koumoundouros et al., 2001) and could be due to an increase of feed intake with temperature as demonstrated by Person-Le Ruyet et al. (2004) in sea bass juveniles. Growth was also influenced by diet and we observed the same ranking of experimental conditions: $\mathrm{HH} 22>\mathrm{LH} 22>\mathrm{HH} 16>\mathrm{LH} 16$. As $\mathrm{HH}$ and $\mathrm{LH}$ diets were isoproteic and isolipidic, significant effect of diet on fresh body weight could only be attributed to their n-3 HUFA content. Our results are in concordance with Zambonino Infante and Cahu (1999), who found that d-38 sea bass larvae fed with a similar diet to $\mathrm{HH}$ one, and reared at $19^{\circ} \mathrm{C}$, had a mean fresh body weight of about 20 mg. Le Milinaire (1984) suggested that a significant effect of dietary HUFA on larval growth was the consequence of the high larvae HUFA requirement needed for high cellular turn-over.

The relatively high level of $n-3$ HUFA measured in PL vs. NL is in accordance to the preferential incorporation of these $\mathrm{FA}$ in $\mathrm{PL}$ contributing to maintenance of phospholipid quality, as described by Linares and Henderson (1991). However, despite high selectivity of DHA in PL and higher DHA content in larvae than in diets, DHA content measured in PL of LH larvae remained low (near 14\%) compared to $\mathrm{HH}$ larvae, revealing a n-3 deficiency in this group. This was also low compared to DHA PL content in European sea bass juveniles (higher than $20 \%$ in fish fed at or above requirement, Skalli and Robin, 2004). The n-3 HUFA content in LH diet (1.1\% DM) was higher than the requirement level for juveniles determined at $0.7 \%$ DM by Skalli and Robin (2004). Total FAME contained in larvae was low compared to lipid content currently observed in juveniles, indicating either intense energetic utilization of dietary FA or imperfect lipid digestion. Requirement of HUFA should cover PL increase with growth and losses induced by turn over (Robin and Skalli, 2007), which should be both more intense in larvae than in juveniles according to relative growth.

Larval skeletal development was highly influenced by temperature and developmental stages were more advanced in larvae reared at $22^{\circ} \mathrm{C}$ than in those conditioned at $16^{\circ} \mathrm{C}$, which is in accordance with results of Koumoundouros et al. (2001) on sea bass larvae. However, a lower total length for a same developmental stage was observed: stage $\mathrm{F}$ was reached by $11 \mathrm{~mm}$-larvae reared at $20^{\circ} \mathrm{C}$, while in our study, stage $\mathrm{F}$ was reached by fish measuring $16 \mathrm{~mm}$ and reared at $22^{\circ} \mathrm{C}$. These differences could be the consequence of differences in the strain or storage procedure used.

Amylase and trypsin secretions measured in pancreas were not significantly different between $\mathrm{d}-25$ and $\mathrm{d}-45$, which indicated that pancreatic maturation was already achieved at d-25, independently of dietary HUFA and rearing temperature. This is in agreement with Zambonino Infante and Cahu (2001), who found that 
secretory function of exocrine pancreas progressively develops and becomes efficient after the third week of life (i.e. d-21). Trypsin and amylase activities can be detected at $d-3$ post hatching, before mouth opening, which suggests that those activities were not induced by food (Zambonino Infante and Cahu, 1994).

The AP/leu-ala ratio is an indicator of the intestinal maturation revealed by the onset of brush border membrane digestion by enterocytes, concurrently with the decline of cytosolic digestion. This leads to the enhancement of membranous enzymatic activities (AP and LAP) and to the decrease of cytosolic enzyme activities (leu-ala; Zambonino Infante and Cahu, 1994). Our study showed that low temperature combined with low dietary HUFA delayed intestinal maturation during all larval stages, while low temperature combined with high dietary HUFA conducted to a late maturation only at $\mathrm{d}-25$ and then larvae compensated at $\mathrm{d}-45$ for this initial maturation retardation. Zambonino Infante and Cahu (1999) already demonstrated the significant effect of dietary HUFA on intestinal maturation of sea bass larvae and showed that an earlier maturation of enterocytes was induced by diets containing more than 2.7\% EPA+DHA ( $\mathrm{HH}$ diet was 2.2\%). Lipase and $\mathrm{PLA}_{2}$ are lipolytic enzymes revealed in very young larvae (d-15). Lipase gene relative expression was significantly different in all groups while its enzymatic activities detected by a nonspecific method were equivalent, which suggested the existence of a posttranscriptional regulation independent of temperature and dietary HUFA and that could be under hormonal control as demonstrated in mammals (Ying et al., 1993), and as evoked for fish by Zambonino Infante and Cahu (1999). However, the use of a non-specific method to measure enzymatic activity means that other enzymatic activities were measured, such as esterase activities. This could hide the real lipase enzymatic activity and explain that non significant differences occurred between groups.

The significant increase in 18:3n-6 content in $\mathrm{LH}$ larvae indicated a desaturation from $18: 2 n-6$ by the $\triangle 6 \mathrm{D}$. This result was supported by the higher relative expression of $\Delta 6 \mathrm{D}$ measured in $\mathrm{LH}$ larvae compared to $\mathrm{HH}$ ones during all the larval stage, which indicated the stimulation of this gene transcription by the HUFA deprived diet, independently of temperature. Nutritional modulation of $\Delta 6 \mathrm{D}$ gene has already been described in gilthead seabream by Seiliez et al. (2003), who identified $18: 2 n-9$, i.e. the $\triangle 6 \mathrm{D}$ desaturation product of dietary $18: 1 n-9$, and by Vagner et al. (in press), who measured a significant increase in $\triangle 6 \mathrm{D}$ gene expression in sea bass juveniles fed a HUFA deprived diet. $\triangle 6 \mathrm{D}$ and $\triangle 5 \mathrm{D}$ desaturation capacity were shown by Mourente and Tocher (1994) in starved gilthead seabream juvenile and by Mourente et al. (2005) in European sea bass.

Transcription of $\triangle 6 \mathrm{D}$ gene is modulated by both peroxisome proliferators (PP) and sterol binding element protein-1 (SREBP-1a and SREBP-1c) (for review see Nakamura and Nara, 2003). PP induce fatty acid oxidation enzymes and desaturases in rodent liver. However, the induction of desaturases by PP is slower than the induction of oxidation enzymes. This delayed induction could be a compensatory response to the increased HUFA demand caused by peroxisome proliferation and induction of FA oxidation (Nakamura and Nara, 2003). Dietary HUFA are ligands for PPAR (Peroxisome Proliferator-Activated Receptors), which form heterodimers with retinoid receptor (RXR) before acting on gene expression (James et al., 2003). It has been showed that the stimulation of the PPAR $\alpha$ was stronger in the presence of polyunsaturated fatty acids than with monounsaturated or saturated FA (Keller et al., 1993) and that diet supplemented with olive, corn, soybean or walnut oil $(<20 \%$ of total calories) suppress lipogenic expression (Ren et al., 1997). Our results 
demonstrated that PPAR $\alpha$ and PPAR $\beta$ gene expressions were not affected neither by temperature nor by diet, which could reflect an adaptive response allowing cells to adjust the changes in the type of fat ingested for efficient cell growth and differentiation (Jump et al., 1996). However, as some post-transcriptional regulations occur, PPARs enzymatic activities could differ from PPARs gene expressions and could be responsible of the stimulation of $\triangle 6 \mathrm{D}$ gene expression. SREBP-1 activates genes for FA synthesis in liver. Sterol regulatory element (SRE) is required for activation of the human $\triangle 6 \mathrm{D}$ gene by SREBP-1. Moreover, the same SRE also mediates the suppression of the $\triangle 6 \mathrm{D}$ gene by HUFA. In this study, the inhibition of $\triangle 6 \mathrm{D}$ gene by HUFA was clearly shown. However, the delayed activation by PP was not found as the expression of PPAR was the same in all groups and their activities were not measured. This could explain that the sharp stimulation of the $\triangle 6 \mathrm{D}$ gene in larvae fed a HUFA deprived diet could be due to other mechanisms: at first, it is likely that SREBP-1a, which is normally high in dividing cells such as cell lines, is still expressed in larvae (a maintain of some primary features has been already observed in seabass larvae) resulting in a possible synergistic stimulation by SREBP-1a and SREBP-1c (the form expressed in differentiated cells including hepatocytes). Second, the affinity between SRE and SREBP could have been stimulated (by posttranscriptional events) in fish fed the HUFA deprived diet. Finally, epigenetic modifications of the $\triangle 6 \mathrm{D}$ gene could have occurred in conditioned fish. Pontoglio et al. (1997) identified hepatocyte nuclear factor $1 \alpha$ (HNF1 $\alpha$ ), which is a homeoprotein that is expressed in liver, kidney, pancreas and digestive tract. They showed that HNF1 a could activate transcription through the participation in the recruitment of the general transcription machinery to the promoter, or through the remodelling of chromatin structure and demethylation that would allow transcription factors to interact with their cognate cis-acting elements.

The high HUFA requirement in marine fish species was hypothesized as an inability to produce HUFA from precursors (18:3n-3 and 18:2n-6), but results obtained in these studies lead to modulate this hypothesis. Some fatty acid biotransformation capacities are potentially present in marine fish and can be stimulated by diet deficiency, but remain insufficient to cover the needs. Some posttranscriptional regulation may also occur, which can lead to a difference between the $\triangle 6 \mathrm{D}$ enzymatic activity and the $\Delta 6 \mathrm{D}$ gene expression. In consequence, our results have to be completed by the enzymatic activity measurements.

\section{Conclusion}

This study clearly showed that even though the existence of $\Delta 6 \mathrm{D}$ gene expression modulation, sea bass was not able to offset the effects of insufficient dietary HUFA on growth and PL fatty acid content. Larvae tended to adapt to a n-3 HUFA deprived diet by stimulation of enzymatic pathways for HUFA desaturation independently of rearing temperature. Nevertheless, the measurement of $\triangle 6 D$ enzymatic activity is required to better understand desaturation-elongation process under extreme HUFA contents in diets. It could also be interesting to know if the $\triangle 6 \mathrm{D}$ gene expression responds to a dietary HUFA gradient and in which tissue level this modulation occurs. Further studies will also be undertaken to check whether an enhanced $\triangle 6 \mathrm{D}$ expression could be maintained in juveniles allowing them to modulate $\triangle 6 \mathrm{D}$ expression in response to variations of dietary HUFA levels. 


\section{Acknowledgements}

This work was supported by an IFREMER (French Institute of Sea Research and Exploitation) and an INRA (National institute of Agronomic Research) grants to the first author. We are grateful to N. Le Bayon, H. Le Delliou, M.M. Le Gall, J. Moriceau, P. Quazuguel and A. Severe for their technical assistance. 


\section{References}

Association of Official Analytical Chemists, 1984. Official methods of analysis of the Association of Analytical Chemists. Williams, S. (Ed.). AOAC, Arlington, VA, 1141pp.

Bessey, O.A., Lowry, O.H., Brock, M.J., 1946. Rapid caloric method for determination of alkaline phosphatase in five cubic millimetres of serum. J. Biol. Chem. 164, 321329.

Bradford, M.M., 1976. A rapid and sensitive method for the quantitation of microgram quantities of protein utilizing the principle of protein-dye binding. Anal. Biochem. 72, 248-254.

Cahu, C.L., Zambonino Infante, J.L., 1994. Early weaning of sea bass (Dicentrarchus labrax) larvae with a compound diet: effect on digestive enzymes. Comp. Biochem. Physiol. 109A, 213-222.

Cahu, C.L., Zambonino Infante, J.L., Takeuchi, T., 2003. Nutritional components affecting skeletal development in fish larvae. Aquaculture 227, 245-258.

Cho, H.P., Nakamura, M., Clarke, S.D., 1999. Cloning, expression, and nutritional regulation of the mammalian delta-6 desaturase. J. Biol. Chem. 274, 37335-37339.

Crane, R.K., Boge, G., Rigal, A., 1979. Isolation of brush border membranes in vesicular form from the intestinal spiral valve of the small dogfish (Scyliorhinus canicula). Biochim. Biophys. Acta 554, 264-267.

Folch, J., Lees, M., Sloane-Stanley, G.H., 1957. A simple method for the isolation and purification of total lipids from animal tissues. J. Biol. Chem. 226, 497-509.

Fuiman, L.A., 1997. What can flatfish ontogenies tell us about pelagic and benthic lifestyles? J. Sea Res. 37, 257-267.

Fuiman, L.A., Polling, K.R., Higgs, D.M., 1998. Quantifying developmental progress for comparative studies of larval fishes. Copeia 1998, 602-611.

Gause, W.C., Adamovicz, J., 1994. The use of the PCR to quantitate gene expression. PCR Methods Appl. 3, 123-135.

Holm, H., Hanssen, L.E., Krogdahl, A., Florholmen, J., 1988. High and low inhibitor soybean meals affect human duodenal proteinase activity differently: in vivo comparison with bovine serum albumin. J. Nutr. 118, 515-520.

lijima, N., Tanaka, S., Ota, Y., 1998. Purification and characterization of bile saltactivated lipase from the hepatopancreas of the red sea bream, Pagrus major. Fish Physiol. Biochem. 18, 59-69. 
James, S.Y., Lin, F., Kolluri, S.K., Dawson, M.I., Zhang, X.K., 2003. Regulation of retinoic acid receptor $\beta$ expression by peroxisome proliferator-activated receptor $Y$ ligands in cancer cells. Cancer Res. 63, 3531-3538.

Jump, D.B., Clarke, S.D., Thelen, A., Limatta, M., Ren, B., Badin, M., 1996. Dietary polyunsaturated fatty acid regulation of gene transcription. Prog. Lipid. Res. 35, 227241.

Kanazawa, A., 1993. Essential phospholipids of fish and crustaceans. In: Fish nutrition in practice, Les Colloques, eds S.J. Kaushik and P. Luquet, Paris: Ed. INRA, 61, 519-530.

Keller, H., Dreyer, C., Medin, J., Mahfoudi, A., Ozato, K., Wahli, W., 1993. Fatty acids and retinoids control metabolism through peroxisome proliferator-activated receptorretinoid X receptor heterodimers. Proc. Natl. Acad. Sci. USA 90, 2160-2164.

Koumoundouros, G., Divanach, P., Kentouri, M., 1999. Ontogeny and allometric plasticity of Dentex dentex (Osteichthyes: Sparidae). Mar. Biol. 136, 561-572.

Koumoundouros, G., Divanach, P., Anezaki, L., Kentouri, M., 2001. Temperatureinduced ontogenetic plasticity in sea-bass (Dicentrarchus labrax). Mar. Biol. 139, 817-830.

Koven, W., Kolkovski, S., Hadas, E., Gamsiz, K., Tandler, A., 2001. Advances in the development of microdiets for gilthead seabream, Sparus aurata: a review. Aquaculture 194, 107-121.

Le Milinaire, C., 1984. Etude du besoin en acides gras essentiels pour la larve de turbot (Psetta maxima L.) pendant la phase d'alimentation avec le rotifère Brachionus plicatilis. Université de Brest (France), 168 pp.

Linares, F., Henderson, R.J., 1991. Incorporation of 14C-labelled polyunsaturated fatty acids by juvenile turbot, Scophtalmus maximus (L.) in vivo. J. Fish. Biol. 38, 335-347.

Lodemel, J.B., Mayhew, T.M., Myklebust, R., Olsen, R.E., Espelid, S., Ringo, E., 2001. Effect of three dietary oils on disease susceptibility in Arctic charr (Salvelinus alpinus L.) during cohabitant challenge with Aeromonas salmonicida ssp. Salmonicida. Aquac. Res. 32, 935-946.

Maroux, S., Louvard, D., Baratti, J., 1973. The aminopeptidase from hog-intestinal brush border. Biochim. Biophys. Acta 321, 282-295.

Marty, Y., Delaunay, F., Moal, J., Samain, J.F., 1992. Changes in the fatty acid composition of the scallop Pecten maximus (L.) during larval development. J. Exp. Mar. Biol. Ecol. 163, 221-234.

Metais, P., Bieth, J., 1968. Détermination de l'a-amylase par une microtechnique. Ann. Biol. Clin. 26, 133-142. 
Mourente, G., Tocher, D.R., 1994. In vivo metabolism of $\left[{ }^{1-14} \mathrm{C}\right]$ linolenic acid $(18: 3 n-$ $3)$ and $\left[{ }^{1-14} \mathrm{C}\right]$ eicosapentaenoic acid $(20: 5 n-3)$ in marine fish: Time-course of the desaturation/elongation pathway. Biochim. Biophys. Acta 1212, 109-118.

Mourente, G., Dick, J.R., Bell, J.G., Tocher, D.R., 2005. Effect of partial substitution of dietary fish oil by vegetable oils on desaturation and oxidation of $\left[1-{ }^{14} \mathrm{C}\right] 18: 3 \mathrm{n}-3$ and $\left[1-{ }^{14} \mathrm{C}\right] 20: 5 \mathrm{n}-3$ in hepatocytes and enterocytes of European sea bass (Dicentrarchus labrax L.). Aquaculture 248, 173-186.

Nakamura, M.T., Nara, T.Y., 2003. Essential fatty acid synthesis and its regulation in mammals. PLEFA 68, 145-150.

Nicholson, J.A., Kim, Y.S., 1975. A one-step L-amino acid oxidase assay for intestinal peptide hydrolase activity. Anal. Biochem. 63, 110-117.

Olsen, R.E, Henderson, R.J., McAndrew, B.J., 1990. The conversion of linoleic acid and linoleic acid to longer chain polyunsaturated fatty acids by Tilapia (Oreochromis) nilotica in vivo. Fish. Physiol. Biochem. 8, 261-270.

Parpoura, A.C.R., Alexis, M.N., 2001. Effects of different dietary oils in sea bass (Dicentrarchus labrax) nutrition. Aquac. Int. 9, 463-476.

Person-Le Ruyet, J., Skalli, A., Dulau, B., Le Bayon, N., Le Delliou, H., Robin, J.H., 2004. Does dietary n-3 highly unsaturated fatty acids level influence the European sea bass (Dicentrarchus labrax) capacity to adapt to a high temperature? Aquaculture 242, 571-588.

Pfaffl, M.W., 2001. A new mathematical model for relative quantification in real-time RT-PCR. Nucleic Acids Res. 29, 2002-2007.

Pfaffl, M.W., Horgan, G.W., Dempfle, L., 2002. Relative expression software tool (REST $\left.{ }^{\circledR}\right)$ for group-wise comparison and statistical analysis of relative expression results in real-time PCR. Nucleic Acids Res. 30, 9-36.

Pontoglio, M., Faust, D.M., Doyen, A., Yaniv, M., Weiss, M.C., 1997. Hepatocyte nuclear factor 1alpha gene inactivation impairs chromatin remodelling and demethylation of the phenylalanine hydroxylase gene. Mol. Cell. Biol. 17, 4948-4956.

Ren, B., Thelen, A.P., Peters, J.M., Gonzales, F.J., Jump, D.B., 1997. Polyunsaturated fatty acid suppression of hepatic fatty acid synthase and S14 gene expression does not require peroxisome proliferator-activated receptor $\alpha$. J. Biol. Chem. 272, 26827-26832.

Ringo, E., Lodemel, J.B., Myklebust, R., Jensen, L., Lund, V., Mayhew, T.M., Olsen, R.E., 2002. The effects of soybean, linseed and marine oils on aerobic gut microbiota of arctic charr Salvelinus alpinus $\mathrm{L}$. before and after challenge with Aeromonas salmonicida. Aquac. Res. 33, 591-606. 
Robin, J.H., Peron, A., 2004. Consumption vs. Deposition of essential fatty acids in gilthead seabream (Sparus aurata) larvae fed semi-purified diets. Aquaculture 238, 283-294.

Robin, J.H., Skalli, A., 2007. Incorporation of dietary fatty acid in European sea bass (Dicentrarchus labrax) - A methodological approach evidencing losses of highly unsaturated fatty acids. Aquaculture 263, 227-237.

Sargent, J., Bell, J.G., Bell, M.V., Henderson, R.J., Tocher, D.R., 1995. Requirement criteria for essential fatty acids. J. Appl. Ichtyol. 11, 183-198.

Sargent, J., McEvoy, L., Estevez, A., Bell, G., Bell, M., Henderson, J., Tocher, D., 1999. Lipid nutrition of marine fish during early development: current status and future directions. Aquaculture 179, 217-229.

Seiliez, I., Panserat, S., Kaushik, S., Bergot, P., 2001. Cloning, tissue distribution and nutritional regulation of a Delta- 6 desaturase-like enzyme in rainbow trout. Comp. Biochem. Physiol. B. 130, 83-93.

Seiliez, I., Panserat, S., Corraze, G., Kaushik, S., Bergot, P., 2003. Cloning and nutritional regulation of a $\Delta 6$-desaturase-like enzyme in the marine teleost gilthead seabream (Sparus aurata). Comp. Biochem. Physiol. 135 (B), 449-460.

Sfakianakis, D.G., Koumoundouros, G., Divanach, P., Kentouri, M., 2004. Osteological development of the vertebral column and of the fins in Pagellus erythrinus (L.1758). Temperature effect on the developmental plasticity and morphoanatomical abnormalities. Aquaculture 232, 407-424.

Skalli, A., Robin, J. H., 2004. Requirement of n-3 long chain polyunsaturated fatty acids for European sea bass (Dicentrachus labrax) juveniles: growth and fatty acid composition. Aquaculture 240, 399-415.

Taylor, W.R., Van Dyke, G.C., 1985. Revised procedures for staining and clearing small fishes and other vertebrates for bone and cartilage study. Cybium II 9, 107-119.

Vagner, M., Zambonino Infante, J.L., Robin, J.H., Person-Le Ruyet, J. Is it possible to influence European sea bass (Dicentrarchus labrax) juvenile metabolism by a nutritional conditioning during larval stage ? Aquaculture, in press.

Ying, Z., Tojo, H., Nonaka, Y., Okamoto, M., 1993. Cloning and expression of phospholipase $A_{2}$ from guinea pig grastric mucosa: its induction by carbachol and secretion in vivo. Eur. J. Biochem. 215, 91-97.

Zambonino Infante, J.L., Cahu, C.L., 1994. Development and response to a diet change of some digestive enzymes in sea bass (Dicentrarchus labrax) larvae. Fish Physiol. Biochem. 12, 399-408.

Zambonino Infante, J.L., Cahu, C.L., 1999. High dietary lipid levels enhance digestive tract maturation and improve Dicentrarchus labrax larval development. J. Nutr. 129, 1195-1200. 
Zambonino Infante, J.L., Cahu, C.L., 2001. Ontogeny of the gastrointestinal tract of marine fish larvae. Comp. Biochem. Physiol. C. 130 (4), 477-487.

Zheng, X., Seiliez, I., Hastings, N., Tocher, D.R., Panserat, S., Dickson, C.A., Bergot, P., Teale, A.J., 2004. Charactarization and comparison of fatty acyl $\Delta 6$-desaturase cDNAs from freshwater and marine teleost fish species. Comp. Biochem. Physiol. 139B, 269-279. 
Table 1. Formulation (g.100 g $\mathrm{g}^{-1}$ ), chemical composition (\% DM) and fatty acid composition in TL (\% FAME) of the two experimental diets (HH and $\mathrm{LH})$.

\begin{tabular}{|c|c|c|}
\hline Ingredients $^{a}$ & $\mathrm{HH}$ diet & LH diet \\
\hline Fish meal LT 94 & 55 & 26 \\
\hline Defatted fish meal & 0 & 28 \\
\hline CPSP 90 & 12 & 12 \\
\hline Soy oil & 0 & 2 \\
\hline Soy lecithin & 15 & 20 \\
\hline Marine lecithin LC 60 & 5 & 0 \\
\hline Vitamin mixture ${ }^{\mathrm{b}}$ & 7.5 & 7.5 \\
\hline Mineral mixture ${ }^{c}$ & 3.5 & 3.5 \\
\hline Betaine & 1 & 1 \\
\hline Cellulose & 1 & 0 \\
\hline \multicolumn{3}{|l|}{ Chemical composition } \\
\hline Dry matter (\%) & 91.9 & 91.1 \\
\hline Crude protein (\% DM) & 55.2 & 58.5 \\
\hline Crude fat (\% DM) & 22.1 & 21 \\
\hline Ash (\% DM) & 14.1 & 14.7 \\
\hline HUFA n-3 (\% DM) & 2.9 & 1.1 \\
\hline \multicolumn{3}{|c|}{ Fatty acids composition in TL } \\
\hline $18: 2 n-6$ & $31.0 \pm 0.1$ & $44.1 \pm 0.1$ \\
\hline $18: 3 n-6$ & $0.1 \pm 0.0$ & $0.1 \pm 0.0$ \\
\hline $20: 4 n-6$ & $0.6 \pm 0.0$ & $0.3 \pm 0.0$ \\
\hline $18: 3 n-3$ & $3.0 \pm 0.0$ & $4.2 \pm 0.0$ \\
\hline $20: 5 n-3$ & $5.5 \pm 0.0$ & $2.3 \pm 0.0$ \\
\hline $22: 6 n-3$ & $9.7 \pm 0.1$ & $3.7 \pm 0.0$ \\
\hline$\Sigma$ saturated & $24.8 \pm 0.2$ & $23.6 \pm 0.2$ \\
\hline$\Sigma$ mono-unsaturated & $23.5 \pm 0.1$ & $21.0 \pm 0.2$ \\
\hline$\Sigma n-6$ & $31.9 \pm 0.1$ & $44.5 \pm 0.1$ \\
\hline$\sum n-3$ & $19.8 \pm 0.2$ & $10.9 \pm 0.2$ \\
\hline
\end{tabular}

a Sources: fish meal LT 94: Norse (Fyllingsdalen, Norway); hydrolysed fish meal: Archimex (Vannes, France); fish protein hydrolysate CPSP 90: Sopropêche (Boulogne sur mer, France); soy oil: Système U (Créteil, France); soy lecithin: Louis François (Saint-Maur, France); marine lecithin LC 60: Phosphotech (Saint-Herblain, France).

${ }^{\mathrm{b}}$ Vitamin mixture (g kg-1 vitamin mix): retinyl acetate, 1; cholecalciferol, 2.5; DL- $\alpha$ tocopheryl acetate, 5; menadione, 1; thiamine-HCL, 0.1 ; riboflavin, 0.4 ; D-calcium panththenate, 2; pyridoxine-HCL, 0.3; cyanocobalamin, 1; niacin, 1; choline, 200; ascorbic acid (ascorbyl polyphosphate), 5; folic acid, 0.1; D-biotin, 1; meso-inositol, 30.

${ }^{\mathrm{c}}$ Mineral mixture (g kg-1 mineral mix): KCL, 90; KI, 0.04; $\mathrm{CaHPO}_{4} 2 \mathrm{H}_{2} \mathrm{O}, 500 ; \mathrm{NaCl}$, 40; $\mathrm{CuSO}_{4} 5 \mathrm{H}_{2} \mathrm{O}, 3 ; \mathrm{ZnSO}_{4} 7 \mathrm{H}_{2} \mathrm{O}, 4 ; \mathrm{CoSO}_{4}, 0.02 ; \mathrm{FeSO}_{4} 7 \mathrm{H}_{2} \mathrm{O}, 20 ; \mathrm{MnSO}_{4} \mathrm{H}_{2} \mathrm{O}, 3 ; \mathrm{CaCo}_{3}$, 215; $\mathrm{MgOH}, 124 ; \mathrm{Na}_{2} \mathrm{SeO}_{3}, 0.03 ; \mathrm{NaF}, 1$. 
Table 2. Primer used for each gene expression analysis by RT-PCR.

\begin{tabular}{lll}
\hline Gene & \multicolumn{1}{c}{ Forward primers (5-3') } & \multicolumn{1}{c}{ Reverse primers (3'-5') } \\
\hline$\Delta 6 \mathrm{D}$ & GCCCTATCATCACCAACACC & ACAGCACAGGTAGCGAAGGT \\
Lipase & TGGATGGCATGATGGAGA & CTGCAGCAGGTGGGCTAT \\
PLA 2 & TCCTGTGTGTGATGCCTGAT & TCTCGTCGCAGTTGTAGTCG \\
PPAR $\alpha$ & ACCTCAGCGATCAGGTGACT & AACTTCGGCTCCATCATGTC \\
PPAR $\beta$ & GCTCGGATCTGAAGACCTTG & TGGCTCCATACCAAACCACT \\
\hline
\end{tabular}


Table 3. $\mathrm{D}-45$ survival rate ( $\mathrm{n}=5$ for $22^{\circ} \mathrm{C}$ - and $\mathrm{n}=7$ for $16^{\circ} \mathrm{C}$-groups), fresh $(\mathrm{n}=120)$ and dry $(n=4)$ body weight, biomass $(n=4)$ and total length $(n=40)$ for each experimental condition. Values are mean $\pm \mathrm{SE}$ and significant effects of temperature $(\mathrm{t})$, diet $(\mathrm{d})$ and interaction are represented ( $* \mathrm{P}<0.05$; $* * * \mathrm{P}<0.001)$.

\begin{tabular}{lccccccc}
\hline Zootechnical values at d-45 & LH16 & HH16 & LH22 & HH22 & t & d & i \\
\hline Survival rate (\%) & $50 \pm 6$ & $54 \pm 5$ & $22 \pm 1$ & $25 \pm 2$ & $*_{* * *}$ & & \\
Fresh body weight (mg) & $15.0 \pm 1.7$ & $18.1 \pm 0.4$ & $84.4 \pm 4.4$ & $94.8 \pm 0.7$ & ${ }^{* * *}$ & $* * *$ \\
Final biomass (mg.l ${ }^{-1}$ ) & $369.9 \pm 5.3$ & $512 \pm 1.1$ & $952.5 \pm 2.8$ & $1229.7 \pm 14.1$ & $* * *$ & $*$ & \\
Total length (mm) & $15.0 \pm 0.1$ & $15.9 \pm 0.2$ & $23.0 \pm 0.4$ & $23.0 \pm 0.4$ & ${ }^{* * *}$ & \\
\hline
\end{tabular}


Table 4. Total quantity of fatty acids methyl esters (FAME) in total lipids TL and neutral lipids NL (mg. ${ }^{-1}$ Fresh Weight) in d-45 larvae according to rearing conditions; FA profiles (in \% FAME) of polar lipids (PL) and NL. Values are mean \pm SE $(n=4)$. Statistical significance of temperature $(\mathrm{t})$, diet (d) and interaction (i) are indicated (* $\mathrm{P}<0.05$, ** $\mathrm{P}<0.01$ and $* * * \mathrm{P}<0.001)$ and values having different letters indicate that treatments are significantly different.

\begin{tabular}{|c|c|c|c|c|c|c|c|}
\hline & \multicolumn{4}{|c|}{ Larval composition } & \multicolumn{3}{|c|}{$\begin{array}{c}\text { Statistical } \\
\text { analysis }\end{array}$} \\
\hline & LH16 & HH16 & LH22 & $\mathrm{HH} 22$ & $\mathrm{t}$ & $\mathrm{d}$ & $\mathrm{i}$ \\
\hline FAME TL mg.g $^{-1}$ & $25.4 \pm 1.0$ & $26.5 \pm 1.9$ & $30.1 \pm 2.0$ & $30.5 \pm 5.3$ & & & \\
\hline FAME NL mg.g ${ }^{-1}$ & $12.6 \pm 0.5$ & $14.4 \pm 1.3$ & $19.2 \pm 1.1$ & $18.5 \pm 4.2$ & * & & \\
\hline \multicolumn{8}{|l|}{ NL } \\
\hline $18: 2 n-6$ & $42.2 \pm 0.3$ & $30.8 \pm 0.1$ & $42.2 \pm 0.2$ & $30.8 \pm 0.1$ & & *** & \\
\hline $18: 3 n-6$ & $0.3 \pm 0.0^{\mathrm{a}}$ & $0.2 \pm 0.0^{\mathrm{a}}$ & $0.7 \pm 0.0^{\mathrm{b}}$ & $0.1 \pm 0.0^{\mathrm{C}}$ & $* * *$ & $* * *$ & *** \\
\hline $20: 4 n-6$ & $0.2 \pm 0.0$ & $0.5 \pm 0.0$ & $0.2 \pm 0.0$ & $0.5 \pm 0.0$ & & $* * *$ & \\
\hline $18: 3 n-3$ & $3.8 \pm 0.0$ & $3.0 \pm 0.0$ & $3.6 \pm 0.0$ & $2.8 \pm 0.0$ & $* * *$ & $* * *$ & \\
\hline $20: 5 n-3$ & $1.5 \pm 0.0$ & $3.8 \pm 0.1$ & $1.8 \pm 0.0$ & $4.2 \pm 0.0$ & $* * *$ & $* * *$ & \\
\hline $22: 6 n-3$ & $2.3 \pm 0.1$ & $6.9 \pm 0.2$ & $2.4 \pm 0.1$ & $7.1 \pm 0.2$ & & $* * *$ & \\
\hline$\Sigma$ saturated & $23.9 \pm 0.3$ & $25.2 \pm 0.3$ & $23.4 \pm 0.4$ & $25.4 \pm 0.2$ & & $* * *$ & \\
\hline $\begin{array}{l}\Sigma \text { mono- } \\
\text { unsaturated }\end{array}$ & $23.3 \pm 0.2$ & $26.3 \pm 0.2$ & $23.6 \pm 0.1$ & $26.3 \pm 0.2$ & * & $* * *$ & \\
\hline$\Sigma \mathrm{n}-6$ & $44.4 \pm 0.2$ & $34.3 \pm 0.1$ & $44.3 \pm 0.3$ & $35.6 \pm 0.1$ & * & $* * *$ & \\
\hline$\Sigma \mathrm{n}-3$ & $8.6 \pm 0.1$ & $15.5 \pm 0.3$ & $8.7 \pm 0.1$ & $15.7 \pm 0.2$ & & $* * *$ & \\
\hline \multicolumn{8}{|l|}{ PL } \\
\hline $18: 2 n-6$ & $36.3 \pm 0.3$ & $21.9 \pm 0.3$ & $32.5 \pm 0.3$ & $19.3 \pm 0.3$ & $* * *$ & $* * *$ & \\
\hline $18: 3 n-6$ & $0.3 \pm 0.0$ & $0.1 \pm 0.0$ & $0.3 \pm 0.0$ & $0.2 \pm 0.0$ & & $* * *$ & \\
\hline $20: 4 n-6$ & $0.8 \pm 0.0$ & $1.5 \pm 0.0$ & $0.9 \pm 0.0$ & $1.6 \pm 0.0$ & $* *$ & $* * *$ & \\
\hline $18: 3 n-3$ & $1.9 \pm 0.0$ & $1.2 \pm 0.0$ & $1.5 \pm 0.0$ & $1.0 \pm 0.0$ & $* * *$ & $* * *$ & \\
\hline $20: 5 n-3$ & $5.0 \pm 0.1^{\mathrm{c}}$ & $9.1 \pm 0.1^{\mathrm{a}}$ & $5.1 \pm 0.1^{\mathrm{c}}$ & $8.5 \pm 0.1^{b}$ & $*$ & $* * *$ & ** \\
\hline 22:6n-3 & $13.2 \pm 0.4$ & $24.1 \pm 0.7$ & $15.3 \pm 0.5$ & $24.2 \pm 0.5$ & & $* * *$ & \\
\hline$\Sigma$ saturated & $27.2 \pm 0.5$ & $26.8 \pm 0.6$ & $28.4 \pm 1.3$ & $27.0 \pm 0.8$ & $* *$ & & \\
\hline$\Sigma$ mono- & & & & & & & \\
\hline unsaturated & $12.4 \pm 0.1$ & $12.2 \pm 0.1$ & $13.2 \pm 0.1$ & $12.9 \pm 0.2$ & *** & $*$ & \\
\hline$\Sigma \mathrm{n}-6$ & $36.7 \pm 0.4$ & $25.5 \pm 0.3$ & $35.6 \pm 0.3$ & $22.2 \pm 0.3$ & $* * *$ & $* * *$ & \\
\hline$\Sigma \mathrm{n}-3$ & $21.0 \pm 0.5$ & $35.5 \pm 0.7$ & $22.7 \pm 0.8$ & $34.6 \pm 0.5$ & & $* * *$ & \\
\hline
\end{tabular}


A

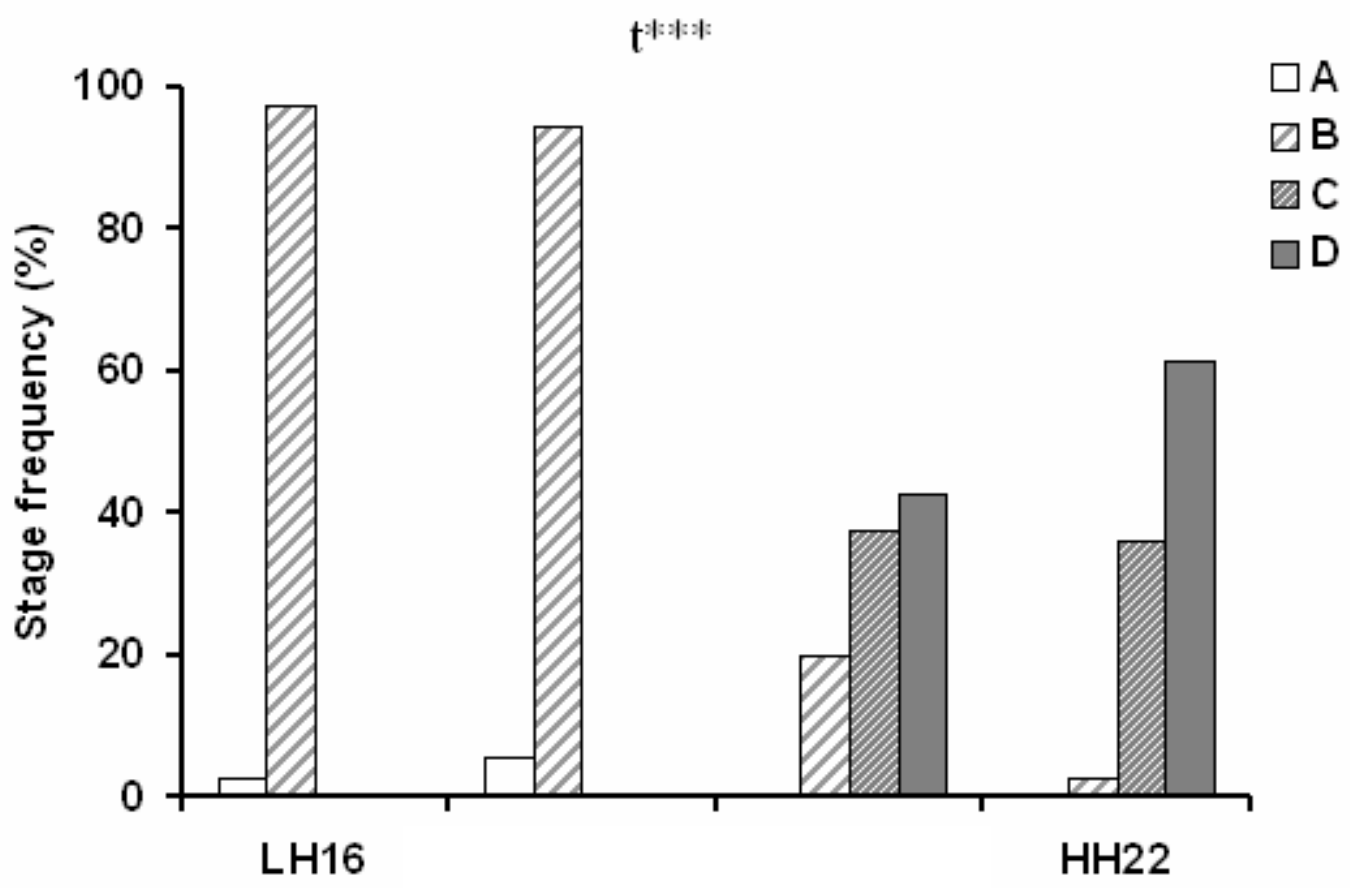

B

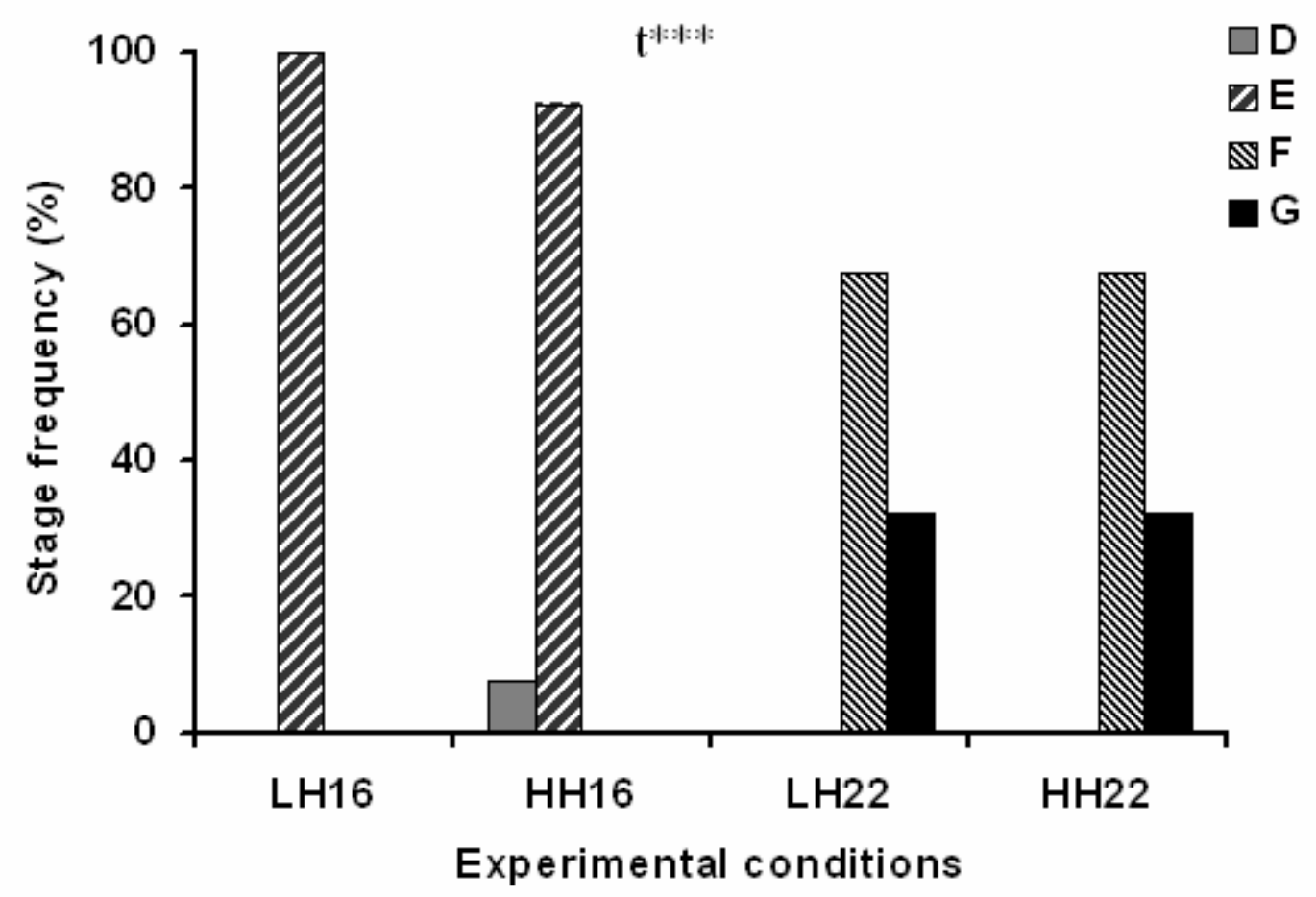

Fig.1. Larvae developmental stage frequency for each experimental conditions at d-25 (A) and at d-45 (B), $n=10$ for each experimental condition. Significant effect of temperature (t) for each sampling day is indicated $(* * * \mathrm{P}<0.001)$. 


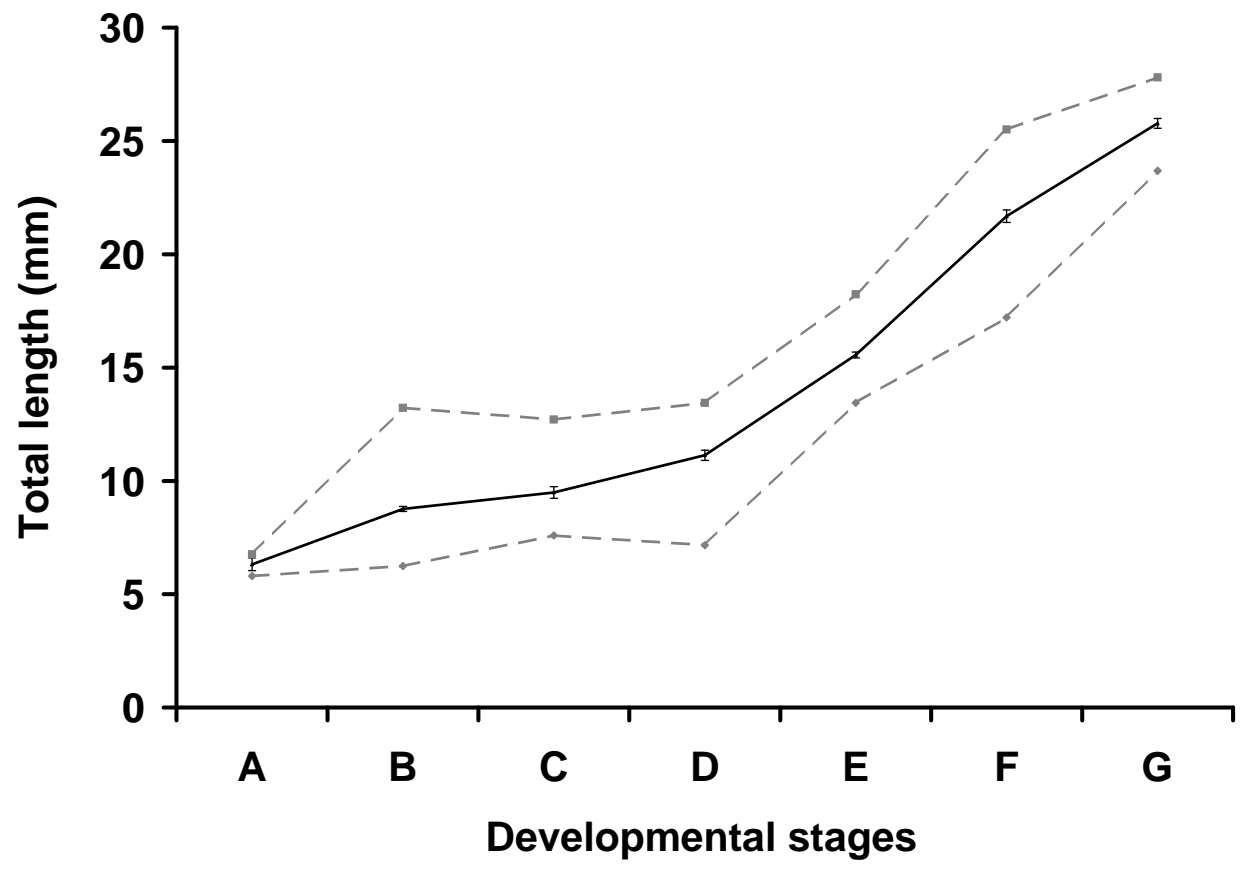

Fig.2. Minimal, maximal (grey dotted lines) and mean \pm SE (black line) length of larvae according to developmental stage. 

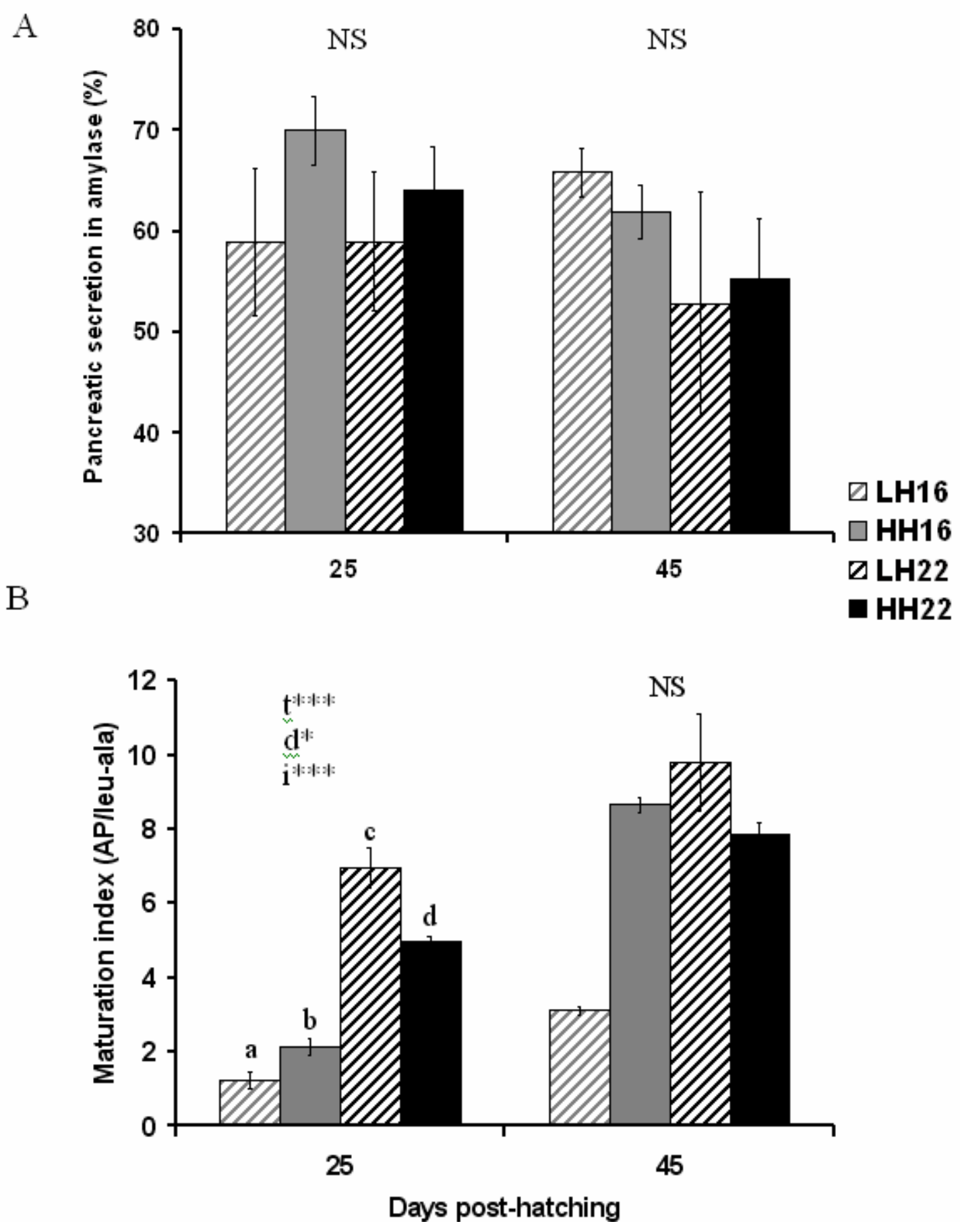

Fig.3. (A) Mean level of pancreatic amylase secretion in d-25 and d-45 larvae, expressed as percent of segmental activity of amylase in the intestinal segment (IS) related to total activity in larvae for each experimental condition. (B) Alkaline phosphatase (AP) maturation index in d-25 and d-45 larvae, expressed as AP activity in brush border membrane (BBM) related to leu-ala activity in IS for each experimental condition. Mean \pm SE $(n=4)$, statistical effect of temperature $(\mathrm{t})$, diet $(\mathrm{d})$ and interaction (i) are indicated for each sampling day $(* \mathrm{P}<0.05$, ** $\mathrm{P}<0.01$, *** $\mathrm{P}<0.001$, NS non significant) and different superscript letters mean significantly different maturation ratio. 
A

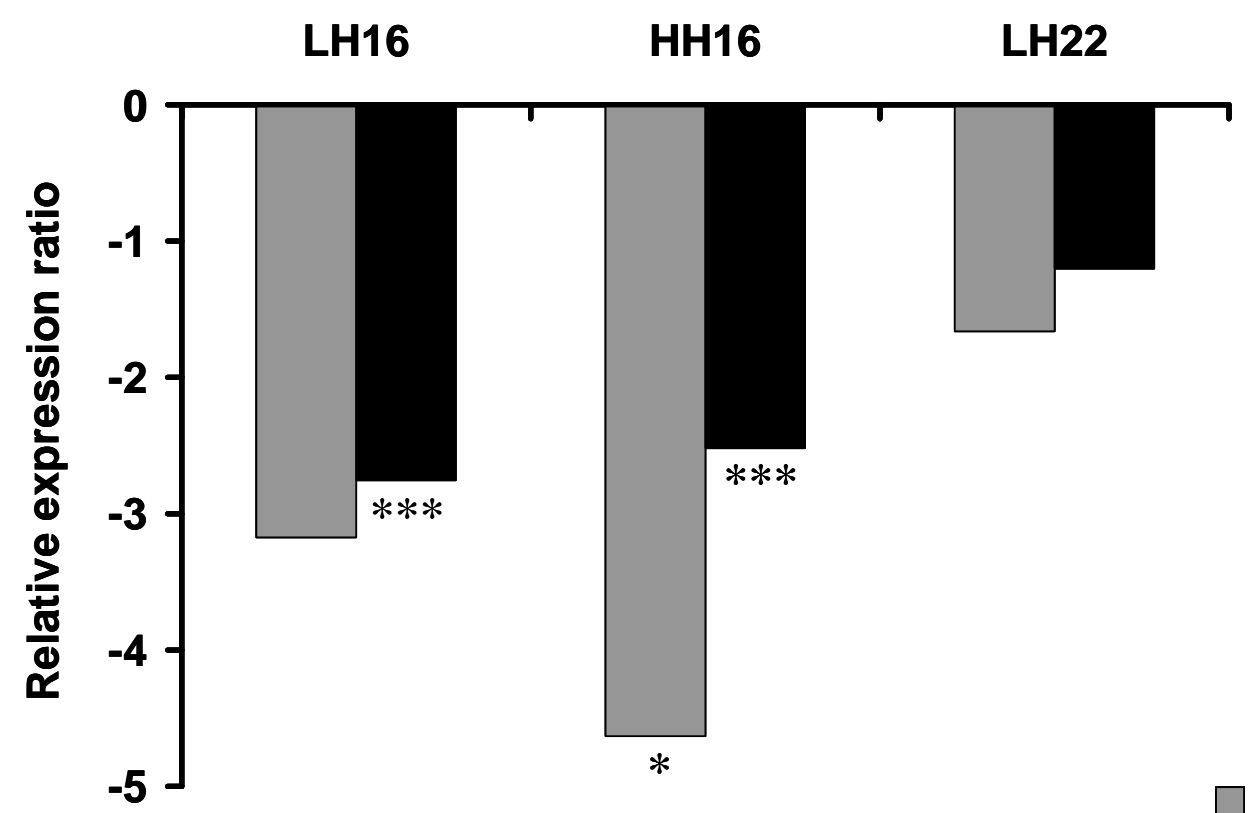

$\mathrm{B}$

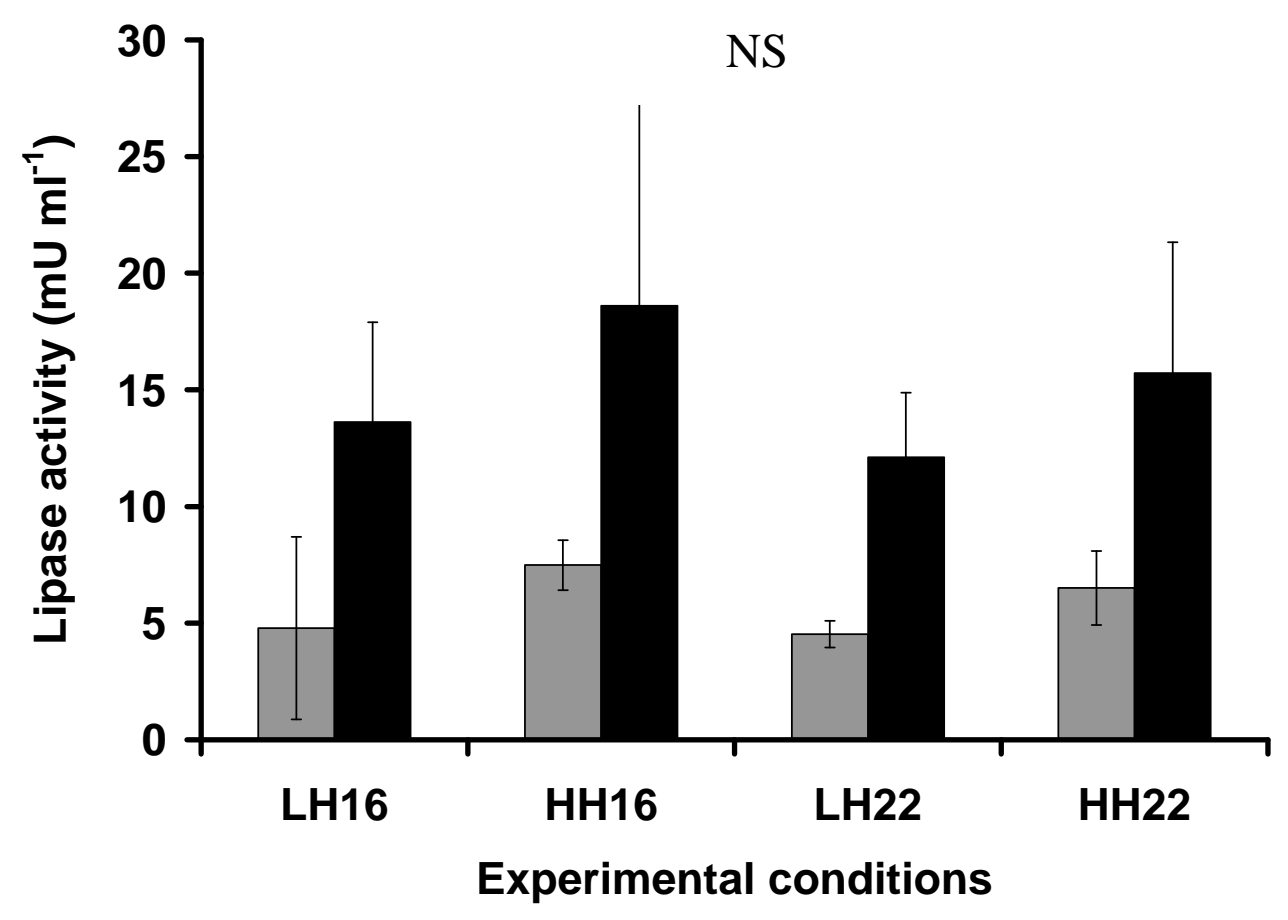

Fig.4. (A) Lipase gene relative expression ratio in d-25 and d-45 larvae for each experimental condition ( $\mathrm{n}=3$ ), with HH22 as the reference. $* \mathrm{P}<0.05$; *** $\mathrm{P}<0.001$ and (B) lipase enzymatic activity (mean \pm SE) in d-25 and d-45 larvae for each experimental condition $(n=$ 4) NS non significant. 
A
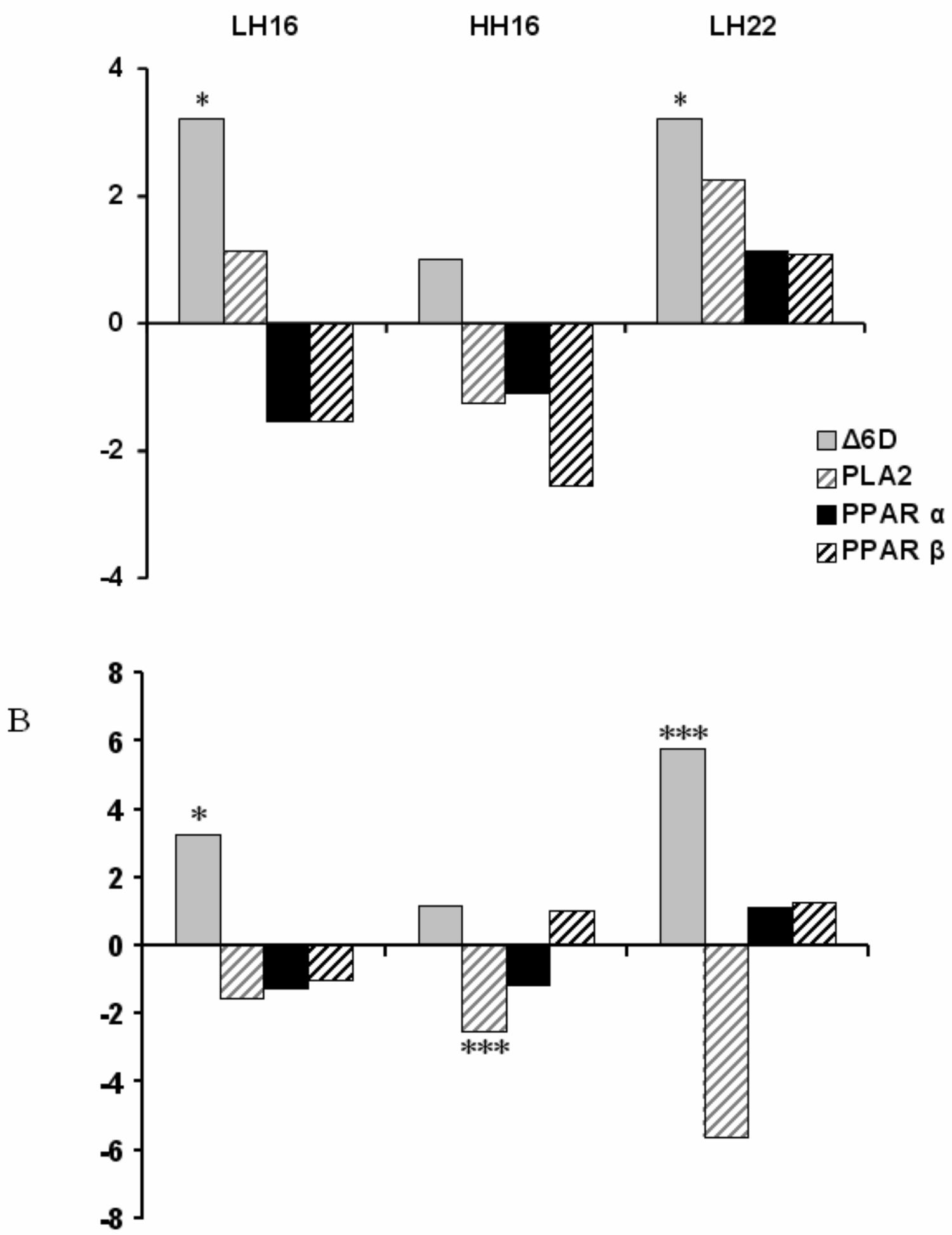

Fig.5. $\Delta 6 \mathrm{D}, \mathrm{PLA}_{2}$, PPAR $\alpha$ and PPAR $\beta$ gene relative expression ratio in d-25 (A) and d-45 (B) larvae for each experimental condition ( $\mathrm{n}=3$ ). ${ }^{*} \mathrm{P}<0.05$; ** $\mathrm{P}<0.01$, *** $\mathrm{P}<0.001$ indicated significant differences with respect to $\mathrm{HH} 22$ reference group. 
A

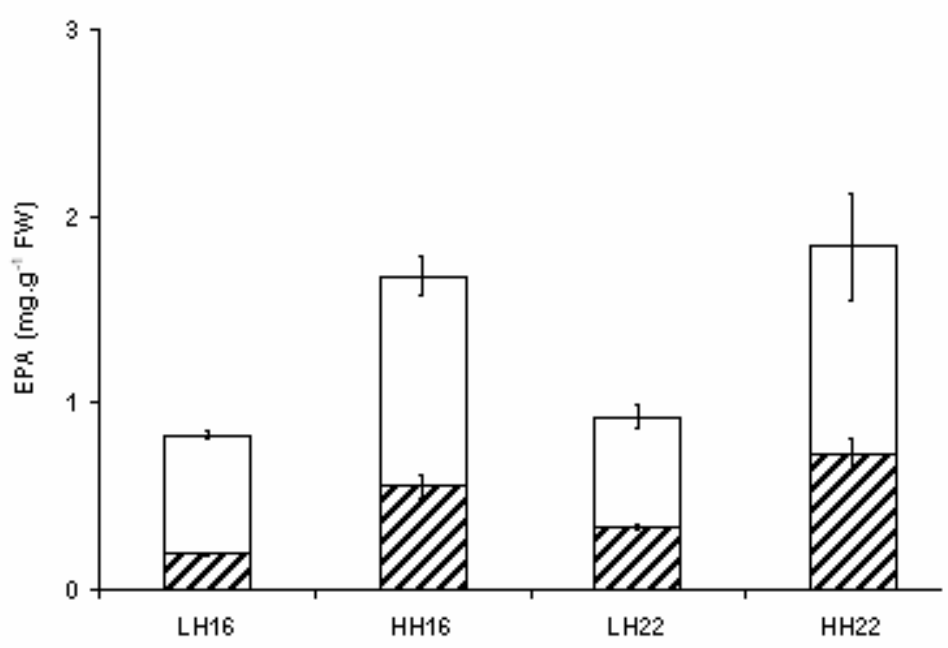

$\mathrm{B}$

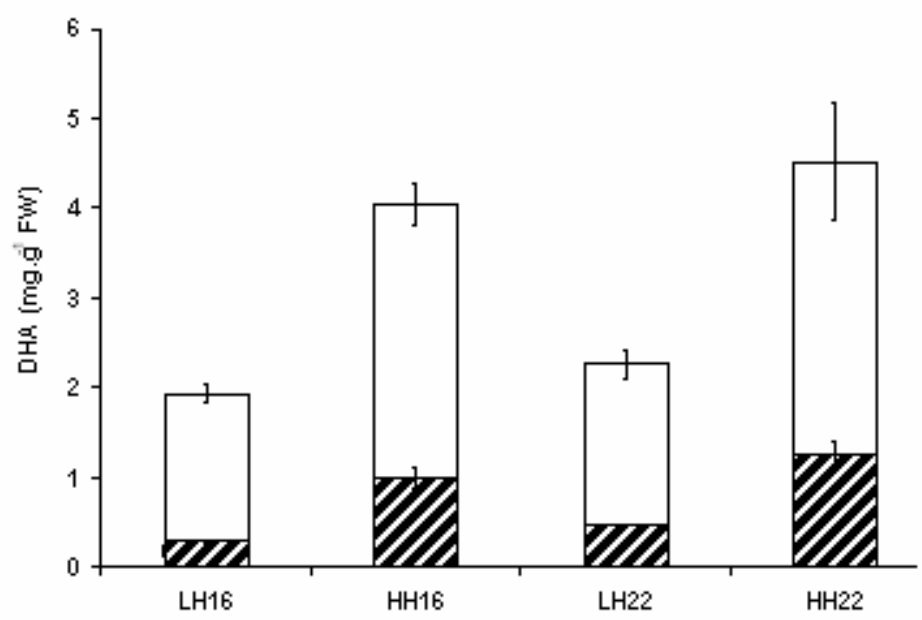

C

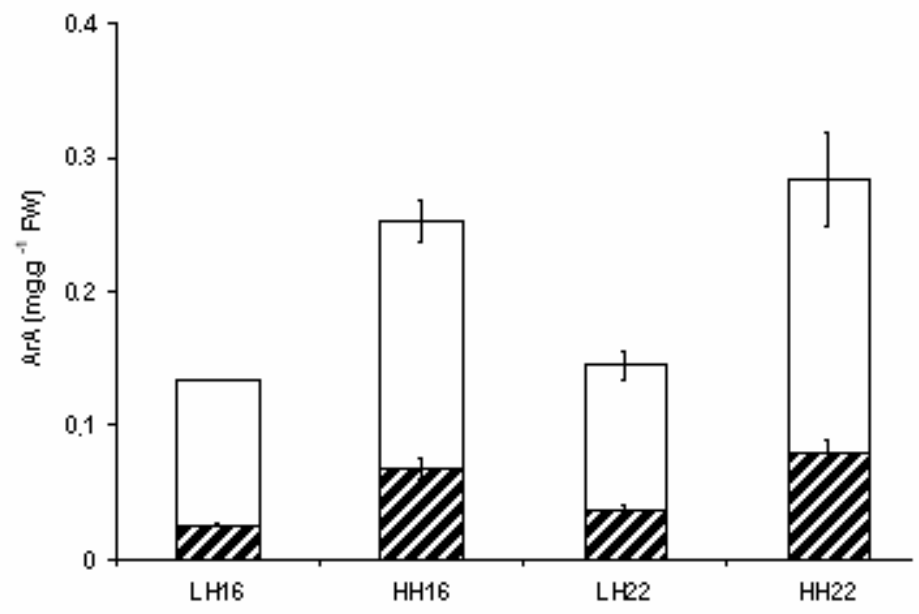

Fig.6. Quantities of DHA, EPA and arachidonic acid (ArA) in d-45 larvae, expressed as mg. ${ }^{-1}$ Fresh Weight (mean $\pm \mathrm{SE}$ ), in TL (total bar) and NL (dashed part) for each experimental conditions; quantities in PL being estimated by difference (white part). 